\title{
Cesium Removal from the Fuel Storage Water at the Savannah River Site R-Building Disassembly Basin Using 3m Empore ${ }^{\circledR}$. Membrane Filter Technology
}

\author{
L. N. Oji, M. C. Thompson, Kurt Peterson, and C. May \\ Westinghouse Savannah River Company \\ Aiken, SC 29808 \\ Thomas M. Kafka \\ 3M Company \\ St. Paul, MN 55144-1000
}

\section{Abstract}

This report describes results from a seven-day demonstration of the use of $3 \mathrm{M}$ Empore ${ }^{\circledR}$ membrane filter loaded with ion exchange material (potassium cobalt hexacynoferrate $(\mathrm{CoHex})$ ) for cesium uptake from the R-Disassembly Basin at the Savannah River Site. The goal of the demonstration was to evaluate the ability of the Process Absorber Development unit (PADU), a water pre-filtration /CoHex configuration on a skid, to remove cesium from R-Disassembly Basin at a linear processing flow rate of 22.7 liters per minute $\left(1,195.8\right.$ liters $/$ minute $/ \mathrm{m}^{2}$ or 29.35 gallons $/$ minute $\left./ \mathrm{ft}^{2}\right)$.

Over 210,000 liters ( $>55,500$ gallons) of R-Disassembly Basin water was processed through the PADU without a cesium breakthrough, that is, the effluent after treatment with CoHex, contained less than detectable amounts of radioactive cesium.

Some of the observed advantages of the Empore ${ }^{\circledR}$ membrane filter technology over conventional packed column ion exchange systems includes rapid flow rates without channeling effects, low volume secondary waste and fast extraction or rapid kinetics per unit of flow.

\section{Introduction}

The R-Reactor Disassembly Basin at the Savannah River Site (SRS), up until 1964 when the R- reactor was shut down, was used mainly for temporary storage of irradiated fuel to remove radioactive decay heat from the fuel assemblies. The basin contains no fuel, target assemblies or other nuclear reactor components. The R-Disassembly Basin pool has an estimated volume of 5 million gallons of tritiated water and 2-3 inches of radioactive sludge on the basin floor. The sludge is primarily made up of corrosion products from aluminum-clad fuel assemblies and debris from underwater machining operations (1). The principal radionuclides of environmental release concerns in the Disassembly Basin are cesium-137, strontium-90 and tritium. The concentrations of cesium-137 and strontium- 90 in the R-Disassembly Basin [Table 2a] exceed the Department of Energy (DOE) release limits of $3000 \mathrm{pCi} / \mathrm{L}$ for Cs-137 and $1000 \mathrm{pCi} / \mathrm{L}$ for Sr-90 (DOE order 5400.5).

One option being considered for the R-Reactor Building Disassembly Basin stabilization (removal of traces of radionuclides) calls for the use of ion exchange-based deactivation technologies to remove cesium-137 and strontium-90. This ion exchange treatment of the basin water will ensure that the deactivated basin 
water will meet DOE ingestion limits. However, although the treated water can be released to site surface water, such direct release decision has not been made yet, because tritium will still be a problem after cesium and strontium have been removed.

Any ion exchange process/equipment set up in the R-Reactor Building Disassembly Basin for removing cesium from the basin water must meet the following minimum requirements:

- Be able to operate with minimum supervision over a long period of time

- Have an auto-shut-off mechanism to control excessive system pressures, spills and leaks

- Generate little or no secondary waste

- The equipment must be easy to maintain.

- The cesium bearing part of the equipment is expected to be under water for shielding purposes.

- The filter housings must meet basic radiation shielding requirements.

- Meet SRS plant safety requirements especially fire hazard requirements.

- Process large volume of water at a fast flow rate.

- Have a high decontamination factor for cesium-137 (>200 at this flow rate).

- The ion exchange material must be capable of functioning in nominal pH environments of 6.5 to 8.5 , and in the presence of ppm levels of competing ions like calcium and strontium- 90 .

- The ion exchange material must be able to withstand low radiation environments (no radiolytic decomposition) due to the accumulation of radionuclides (cesium-137 and strontium-90).

- The return water (cesium-137 or strontium-90 decontaminated water) must meet initial water chemistry quality, that is, no introduction of other chemicals resulting from ion exchange counterions.

This demonstration project, which was carried out at the Vertical Tube Storage area of the R-Reactor Building Disassembly Basin, was aimed at evaluating technology which allows ion specific separations to concentrate low levels of cesium with the generation of minimum secondary waste. The $3 \mathrm{M}$ empore ${ }^{\circledR}$ technology that was evaluated for this cesium removal project was developed with support from the Department of Energy Efficient Separations and Processing (ESP) Crosscutting Program. Previous lowvolume flow rate demonstrations with this technology had been carried out at the Pacific Northwest National Laboratory (PNNL) (2) and 3M at Idaho National Engineering Environmental Laboratory (INEEL) (3).

The objectives of this ion exchange treatment project were:

1. To demonstrate the use of $3 \mathrm{M}$ empore ${ }^{\circledR}$ membrane/ion exchange filter integrated system as a unit that could be used to remove cesium from R-Disassembly Basin at a flow rate up to 22.7 Liters (6 gallons) per minute

2. To process a larger volume of cesium contaminated wastewater than had been previously demonstrated with the Process Absorber Development unit (PADU)

3. To obtain comparative cesium removal field data on the effectiveness of the new configuration for the (spiral wound) web-like $3 \mathrm{M}$ membrane in a cartridge

4. To acquire field data on the regularity with which the coarse and fine pre-filters of the PADU will need to be changed under the R-Disassembly Basin conditions

5. To provide field data for the scale up of the technology to a 190 liters (50 gallons) per minute using the R-Disassembly Basin pool.

\section{Equipment Description}

The Empore ${ }^{\circledR}$ web-like membrane developed by $3 \mathrm{M}$ is an inert matrix of polytetrafluoroethylene fibrils, 
which can be loaded with element selective ion exchange material. In this case of cesium removal, potassium cobalt hexacynoferrate (CoHex) is the active agent. The resulting membrane is configured into a cartridge and inserted into commercial filter housing. It is in this cartridge form that the CoHex is used in the R-Disassembly Basin cesium removal demonstration. The $3 \mathrm{M}$ absorber cartridge physical properties are summarized in Table 1. An effective pre-filtration component of the Process Absorber Development unit ( 0.45 micron coarse filter and 0.1 micron fine filter) was used upstream of the empore cartridges to remove R-Disassembly Basin particulate and prevent the clogging of the empore ${ }^{\circledR}$ cartridges during lengthy operation periods without supervision.

\section{PADU Skid Design and Modification}

The Process Absorber Development unit (PADU) consists of: a portable skid unit containing pumps, piping, pre-filter system, and the $3 \mathrm{M}$ empore ${ }^{\circledR}$ membrane /CoHex cartridge. Figures $1 \mathrm{a}, 1 \mathrm{~b}$ and $1 \mathrm{c}$ are, respectively, the PADU schematic diagram, the engineering design flow diagram and the photo. As mentioned above, this PADU was previously used to treat the waste-water at 105-N Basin at Hanford for cesium-137 and strontium-90 removal. In order to meet the needs of the R-Disassembly Basin demonstration, the PADU was decontaminated and modified at the Savannah River Technology Center. In detail, the modified PADU consisted of:

- Two pre-filters assemblies. Each pre-filter is housed in a high-pressure stainless steel vessel. Both the coarse filter (first pre-filter unit) and the fine filter (second pre-filter unit) contained six filter cartridges with pore size of 0.45 and 0.1 microns, respectively. The six filter cartridges were arranged in parallel inside each vessel and the two vessels were connected in series. The coarse filter was connected directly to the R-Disassembly Basin water intake line via a 3.1-meter long stainless steel pipe (ID of $2.54 \mathrm{~cm}$ ). Each pre-filter unit was equipped with a pressure gauge, a sampling port and a pressure release/water drain valve.

- Two positive displacement pumps arranged in parallel. The pumps could deliver water at approximately 3.78 and 22.71 liters per minute, respectively. Thus, the PADU could be operated at either 3.78 or 22.71 liters per minute. In this demonstration the PADU was operated in the 22.71 liters per minute mode.

- A high-pressure stainless steel vessel containing the $3 \mathrm{M}$ empore ${ }^{\circledR} / \mathrm{CoHex}$ membrane. This unit trapped the radioactive cesium and was lowered about three feet into the basin water for shielding purposes. This vessel was also equipped with pressure gauge/pressure release valve and was connected to the rest of the PADU unit (about 30 meters away via a one-inch copper tubing) via a totalizing flow meter. The $3 \mathrm{M}$ empore ${ }^{\circledR} / \mathrm{CoHex}$ membrane vessel was lowered into the basin water with a winch on a swing-A-frame crane unit. A 10-meter long copper line (effluent line) from the $3 \mathrm{M}$ empore ${ }^{\circledR} / \mathrm{CoHex}$ membrane vessel contained a valve for obtaining samples before the treated RDisassembly Basin water was returned into the disassembly basin.

- A 24-hour clock wired to indicate a self shut-off time, which by design was expected to take place when the pressure readings on the pre-filters is either above 100psi or below 15 psi.

- A high and low-pressure guard circuits. The high-pressure switch, located on the intake side of the PADU pre-filter system, was designed to initiate a shut- off of the PADU if the pressure reading on any of the pre-filters goes above 100 psi due to clogging. The low-pressure switch located after the fine guard filter, on the other hand, initiates the PADU shut-off when the PADU pressure is lower than 15 psi due to a leak in the PADU.

- The R-Disassembly Basin water intake orifice, about 1.53 meters down the basin, was guarded with an inlet strainer made of stainless steel. The strainer prevented large particles from going into the prefilter units.

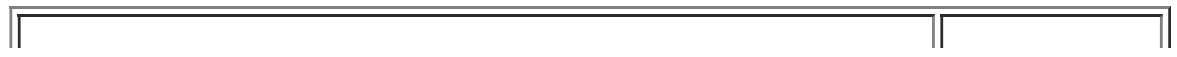




\begin{tabular}{||l||l||}
\hline Adsorber & CoHex \\
\hline Adsorber weight per cartridge & $130 \mathrm{gm}$ \\
\hline Cartridge height & $25.4 \mathrm{~cm}$ \\
\hline Cartridge diameter & $6.35 \mathrm{~cm}$ \\
\hline Membrane Length & $101.6 \mathrm{~cm}$ \\
\hline Membrane width & $24.13 \mathrm{~cm}$ \\
\hline Membrane thickness & $0.1524 \mathrm{~cm}$ \\
\hline \hline Adsorber bed volume [volume of active membrane] & 0.374 Liters \\
\hline
\end{tabular}

Table 1. Adsorber cartridge properties (Information from 3M).

\section{Basin Water Quality and Field Test Operation}

During the winter months when the major part of this PADU demonstration was carried out, a thin offwhite layer of glassy and light reflecting film was observed on the surface of the R-Disassembly Basin pool. The film layer, which is probably composed of calcium precipitate and dust particles, made it difficult to see any item introduced into the basin water. During the warmer spring/summer months most of the film material was gone, and it was now quite easy to operate remote handling tools in the basin without any transparency problems associated with the water clarity. The appearance and disappearance of the off-white film seems to be associated with basin water temperature, which is quite cold in winter (R-Building Disassembly Basin areas are not heated in winter). The surface film material may be transition phases resulting from solubility changes of calcium compounds in cold winter months versus warmer months. The Disassembly Basin contains more than 10 ppm calcium.

The $\mathrm{pH}$ of the R-Disassembly Basin ranges from 7.06 to 7.66 with an average of 7.35 (ref. 1). The R-basin water quality data are summarized in Tables $2 \mathrm{a}$ and $2 \mathrm{~b}$ below. The average values are based on data from individual sections of the $\mathrm{R}$ disassembly basin.

Before running the R-Disassembly Basin water through the PADU, a final system check involved the pumping of more than 6,800 liters of distilled water through the PADU. During these trial runs the PADU was checked for leaks, sampling procedures, and auto shut down responses resulting from system pressure greater than $100 \mathrm{psi}$ and lower than $15 \mathrm{psi}$. The last two conditions were simulated by valve restrictions and intentionally inducing leaks in the PADU. After these check tests, the PADU required no monitoring other than periodic check for leaks during sampling periods. No leaks were observed during the demonstration.

The stainless steel housing containing the six CoHex cartridges was lowered into the basin (1.53 meters) and remained submerged in the basin through out to provide radioactive shielding. The processed water was returned to the basin about 30 meters from the intake point near the PADU to prevent agitation of the disassembly basin water.

Samples were collected from three different sampling locations or ports on the PADU (Figure 1a and 1b): pre-filtration samples (samples collected before entering filter housings \#3 and 1), post pre-filtration samples (after leaving filter housing \#3 and 1) and post cesium decontamination through $3 \mathrm{M}$ Empore ${ }^{\circledR}$ filter samples (filter housing \#2). Each sampling port was fitted with a toggle switch, which could be flushed before sample collection. During the first four days of continuous operation of the PADU, samples were collected from each of the three ports at intervals of two hours beginning at 0900 hours $(0900,1100,1300$ and 1500 hours). A total of 12 samples were collected on a typical 24 hour time period (Table 3). Samples were collected in labeled $250-\mathrm{mL}$ high-density polyethylene bottles, which were pre-rinsed with liquids from 
each specific sampling port before being filled to the 200-mL mark. External radiation measurements were made on the outside of the stainless steel pre-filter housings during each sampling period. The maximum radiation reading on the external pre-filter housing, $200 \mathrm{cpm}$ ([beta]/[gamma]), was not that different from the initial background reading of the decontaminated PADU. After approximately 74 hours of continuous running of the PADU the coarse pre-filter was changed due to clogging of the filter with particulate from the basin. The maximum activity on the clogged coarse pre-filters was $2000 \mathrm{cpm}$ ([beta]/[gamma]).

A sodium iodide (NaI (TI)) scintillation detector, housed in a lead shielded cavity to eliminate background influence from the disassembly basin, and interfaced to a computer was used in the field to obtain approximate activity for cesium-137 in all influent and effluent samples collected (gamma ray spectrum for Cs-137 at $\sim 662 \mathrm{KeV}$ ). A one-hour delay time in the estimation of cesium activity in the samples using the field detector was employed to minimize the effect of barium-137 (daughter products of cesium-137 with a half-life of 30 minutes). The Analytical Development Section (ADS) carried out the final analytical quantification for cesium in all collected samples at the Savannah River Technology Center.

\begin{tabular}{|l|l||}
\hline \multicolumn{1}{|c|}{ Radionuclide } & Average concentration or activity in R-Basin Liquid. \\
\hline Total beta/gamma & $243 \mathrm{~d} / \mathrm{m} / \mathrm{ml}$ \\
\hline Tritium & $0.041(\mu \mathrm{Ci} / \mathrm{mL})$ \\
\hline \hline Cesium-137 & $8.25 \mathrm{E}-05(\mu \mathrm{Ci} / \mathrm{mL})$ \\
\hline Strontium-90 & $23.5 \mathrm{pCi} / \mathrm{mL}$ \\
\hline Co-60 & Not determined \\
\hline Am- 241 & Not determined \\
\hline
\end{tabular}

Table 2a. Summary of average radionuclide concentration in R-Reactor Disassembly Basin (Ref. 1).

\begin{tabular}{|l||l||}
\hline Cation/Anion & R-Basin Liquid ( Average concentrations) (mg/L) \\
\hline $\mathrm{Ca}$ & 12.275 \\
\hline $\mathrm{B}$ & 0.029 \\
\hline $\mathrm{Al}$ & 0.104 \\
\hline $\mathrm{Ba}$ & 0.006 \\
\hline $\mathrm{Ag}$ & $6 \mathrm{E}-05$ \\
\hline $\mathrm{Cd}$ & $8 \mathrm{E}-05$ \\
\hline $\mathrm{Co}$ & $7 \mathrm{E}-05$ \\
\hline $\mathrm{Cr}$ & $1.65 \mathrm{E}-03$ \\
\hline $\mathrm{Cu}$ & $8.4 \mathrm{E}-04$ \\
\hline $\mathrm{Fe}$ & 0.12 \\
\hline $\mathrm{K}$ & 27.57 \\
\hline $\mathrm{Mg}$ & 0.486 \\
\hline $\mathrm{Mn}$ & 0.0274 \\
\hline $\mathrm{Na}$ & 16.475 \\
\hline $\mathrm{Ni}$ & $5.9 \mathrm{E}-4$ \\
\hline $\mathrm{N}$ & \\
\hline
\end{tabular}




\begin{tabular}{||l||l||}
\hline $\mathrm{Pb}$ & $6.0 \mathrm{E}-4$ \\
\hline $\mathrm{Si}$ & 0.093 \\
\hline $\mathrm{Sn}$ & 1.32 \\
\hline $\mathrm{Zn}$ & $7.1 \mathrm{E}-4$ \\
\hline $\mathrm{Sn}$ & 0.0145 \\
\hline $\mathrm{NO}_{3}$ & 1.10 \\
\hline $\mathrm{NO}_{2}$ & 0.23 \\
\hline $\mathrm{SO}_{4}$ & 3.3 \\
\hline $\mathrm{PO}_{4}$ (Total) & 0.02 \\
\hline $\mathrm{F}$ & 0.31 \\
\hline $\mathrm{Cl}$ & 12.2 \\
\hline $\mathrm{Br}$ & 26.8 \\
\hline
\end{tabular}

Table 2b. Summary of principal cation and anion concentration in R-Reactor Disassembly Basin. (Ref. 1).

\begin{tabular}{|c|c|c|c|c|c|c|c|c|}
\hline $\begin{array}{l}\text { Process" } \\
\text { Time, } \\
\text { (hour) }\end{array}$ & $\begin{array}{l}\text { Coanse } \\
\text { filter } \\
\text { pressure } \\
\text { (psi) }\end{array}$ & $\begin{array}{l}\text { Fine } \\
\text { filter } \\
\text { pressure } \\
\text { (psi) }\end{array}$ & Clock & $\begin{array}{l}\text { R-Basin } \\
\text { Feed. } \\
\text { [Cs-137] }^{+} \\
(\mu \mathrm{Ci} / \mathrm{mL})\end{array}$ & $\begin{array}{l}\text { CoHex } \\
\text { Effluent. } \\
\text { [Cs-137] }^{+} \\
(\mu \mathrm{Ci} / \mathrm{mL})\end{array}$ & $\begin{array}{l}\text { Vohume } \\
\text { processed } \\
\text { (Lilers) }\end{array}$ & $\begin{array}{l}\text { Bed vohme } \\
\text { (BV) } \\
\text { BV= 2.244L } \\
\left(0.374 L^{*} 6\right)\end{array}$ & $\begin{array}{l}\text { Sampling } \\
\text { Date }\end{array}$ \\
\hline 05 & 29 & 29 & 1440 & $8.79 \mathrm{E}-05$ & $00^{\prime}$ & 5,09506 & $2,70.53$ & $2 / 1098$ \\
\hline 1 & 29 & 29 & 1540 & $8.19 \mathrm{E}-05$ & 00 & 6,34560 & 2,82780 & $2 / 1088$ \\
\hline 16 & 36 & 30 & 0900 & $803 E-05$ & 00 & $29,385.11$ & 13,00500 & $2 / 1198$ \\
\hline 18 & 38 & 31 & 1100 & $863 E-05$ & 00 & $32,059.40$ & $14,286.72$ & $2 / 11 \theta 8$ \\
\hline 20 & 39 & 31 & 1300 & $-"$ & 00 & $34,741.46$ & 15,48193 & $2 / 1198$ \\
\hline 22 & 40 & 31 & 1500 & $8.73 E-05$ & 00 & $37,398.75$ & $16,666.11$ & $2 / 1198$ \\
\hline 40 & 47 & 32 & 0900 & - & 00 & 61,37302 & 27349.83 & $2 / 12 \theta 8$ \\
\hline 42 & 48 & 32 & 1100 & $809 \mathrm{E}-05$ & 00 & 64,04485 & $28,540.49$ & $2 / 1298$ \\
\hline 44 & 49 & 32 & 1300 & - & 00 & 66,60094 & 29,71967 & $2 / 12 \theta 8$ \\
\hline 46 & 50 & 32 & 1500 & $8.48 \mathrm{E}-05$ & 00 & 69,32833 & 30,89498 & $2 / 12 \theta 8$ \\
\hline 64 & 58 & 32 & 0900 & - & 00 & 93,14128 & 41,50681 & $2 / 13 \theta 8$ \\
\hline 66 & 58 & 32 & 1100 & $8.18 \mathrm{E}-05$ & 00 & 95,62424 & 4261330 & $2 / 13 B 8$ \\
\hline 68 & 60 & 32 & 1300 & $8.41 \mathrm{E}-05$ & $5.14 \mathrm{E}-8$ & 98,94367 & 44,00255 & $2 / 13 \theta 8$ \\
\hline 70 & 60 & 33 & 1500 & $782 E-05$ & 00 & $100,501.67$ & 44,82595 & $2 / 13 \theta 8$ \\
\hline 72 & 60 & 33 & 1300 & $854 E-05$ & 00 & $106,599.98$ & $47,504,45$ & $2 / 1798$ \\
\hline 74 & 61 & 33 & 1500 & $8.76 \mathrm{E}-05$ & 00 & $108,732.07$ & 48,45458 & $2 / 1798$ \\
\hline coasse & filter & changed & & & coarse & filter & changed. & 30098 \\
\hline 0 & 38 & 36 & 1300 & $7.76 \mathrm{E}-05$ & 00 & $113,036.38$ & $50,372.72$ & 30008 \\
\hline 2 & 38 & 36 & 1500 & $8.4 \mathrm{SE}-05$ & 00 & $115,488.68$ & 51,46554 & 300,08 \\
\hline 20 & 45 & 38 & 0900 & - & 00 & $130,825.47$ & 62,31082 & $3 / 10 \theta 8$ \\
\hline 22 & 55 & 39 & 0900 & $8.10 \mathrm{E}-05$ & 00 & $171,501,00$ & $76,425.47$ & $3 / 1198$ \\
\hline 25.5 & 56 & 39 & 1430 & $833 \mathrm{E}-05$ & 00 & $178,493.03$ & 79,54235 & $3 / 1198$ \\
\hline 44 & 65 & 40 & 0900 & $8.73 \mathrm{E}-05$ & 00 & $203,140.95$ & 90,52527 & $3 / 12 \theta 8$ \\
\hline 49.45 & 67 & 40 & 1445 & $807 \mathrm{7E}-05$ & 00 & $210,167.80$ & 93,65767 & $3 / 1298$ \\
\hline Averagp & $\begin{array}{l}\text { WA=Wot } \\
\text { applicable }\end{array}$ & NÁ & FÁ & $\begin{array}{l}8340 \mathrm{E}-05 \pm \\
0245 \mathrm{E}-05\end{array}$ & $\approx 0.0$ & WA & FÁ & FA \\
\hline
\end{tabular}

"* Process time in hours is interval between sampling periods.

+ Weight mean activity; ADS \#s 3-104464 to 3104468 and 3107658 to 3107706.

+ Weight mean activity; ADS \# 3-104464 to 3104468 and 3107658 to 3107706.

* Less than minimum detection limit; averaged $2.277 \mathrm{E}-07$ and $6.523 \mathrm{E}-08 \mu \mathrm{Ci} / \mathrm{mL}$ for 1000 seconds and 10,000 seconds real time counting, respectively.

"Feed was not analyzed. 


\section{Table 3. Summary of PADU data. Coarse pre-filter was changed after the first 74 hours of continuous operation.}

\section{Results and Discussuons}

External radiation activity measurements for the stainless steel pre-filter housings were never greater than $400 \mathrm{dpm} / \mathrm{mL}$ [beta]/[gamma] at $30 \mathrm{~cm}$, indicating that no appreciable amount of radioactive cobalt particles were present or trapped on the pre-filter units as was expected. The slightly higher than background reading on the housings were due to incomplete decontamination of the PADU.

Field estimates of cesium activity in all samples collected, using the portable sodium iodide scintillation detector, showed that the CoHex treated samples had no detectable cesium activity. Both the pre-filter and post filter basin water samples responded positively to cesium activity. The analytically determined average cesium concentration in the R-Disassembly Basin (Vertical tube storage area) is $8.34 \mathrm{E} \pm 0.245 \mathrm{E}-05$ $\mu \mathrm{Ci} / \mathrm{mL}$ (Table 3). This value is consistent with a value of $8.25 \mathrm{E}-05 \mu \mathrm{Ci} / \mathrm{mL}$ (Table $2 \mathrm{a}$ ) documented in previous reports on the R-disassembly basin water chemistry (Ref. 1). The cesium concentration in the basin water samples coming through the CoHex filter, after processing more than 210,000 Liters (55,000 gallons) of basin water, was less than the cesium-137 minimum detection limit of $2.277 \mathrm{E}-07 \mu \mathrm{Ci} / \mathrm{mL}$ (gamma scan counting time of 1000 seconds with average mean activity uncertainty of $2.44 \%$ ). As a result, a value of zero was assigned to the entire CoHex treated samples; in other words, there was no cesium breakthrough after processing over 210,000 Liters (55,000 gallons) of the disassembly water.

Since the cesium decontamination factor, $\mathrm{D}_{\mathrm{f}}$ (initial cesium concentration in the basin/final cesium concentration), at this detection limit is undefined because the final cesium concentration in the CoHex treated samples was assigned a value of zero, the minimum $\mathrm{D}_{\mathrm{f}}$ was estimated by using the magnitude of the minimum detection limit as being equivalent to the final cesium concentration. Based on this assumption, the estimated $\mathrm{D}_{\mathrm{f}}$ value is $366(8.34 \mathrm{E} \mathrm{E}-05 \mu \mathrm{Ci} / \mathrm{mL} / 2.277 \mathrm{E}-07 \mu \mathrm{Ci} / \mathrm{mL})$. To estimate an upper limit for the $\mathrm{D}_{\mathrm{f}}$ value, one of the CoHex treated samples was re-analyzed for cesium by counting for 10,000 seconds instead of 1000 seconds. A new minimum detection limit of $6.523 \mathrm{E}-08 \mu \mathrm{Ci} / \mathrm{mL}$ with a higher activity uncertainty of $28.29 \%$ was established. The value of cesium concentration in this particular sample, at this new and lower detection limit was $5.14 \mathrm{E}-08 \mu \mathrm{Ci} / \mathrm{mL}$ (Table 3). Thus, the upper calculated $\mathrm{D}_{\mathrm{f}}$ limit is 1,623 (8.34E E-05 $\mu \mathrm{Ci} / \mathrm{mL} / 5.14 \mathrm{E}-08 \mu \mathrm{Ci} / \mathrm{mL}$ ). This large $\mathrm{D}_{\mathrm{f}}$ value shows that the cesium uptake efficiency by $\mathrm{CoHex}$, in the presence of competing ions like potassium and sodium (cesium selectivity), is significantly large.

The DOE release limit for cesium-137 is $3000 \mathrm{pCi} / \mathrm{L}(3 \mathrm{pCi} / \mathrm{mL})$. To attain this compliance limit for the $\mathrm{R}$ disassembly basin cesium concentration of $8.34 \mathrm{E} \mathrm{E}-05 \mu \mathrm{Ci} / \mathrm{mL}$ using CoHex ion exchange technology, the expected $\mathrm{D}_{\mathrm{f}}$ is $27.8(8.34 \mathrm{E} \mathrm{E}-05 \mu \mathrm{Ci} / \mathrm{mL} / 3 \mathrm{pCi} / \mathrm{mL})$. Hence, using PADU/CoHex set up for treating the Rdisassembly basin, the minimum estimated cesium decontamination factor, $\mathrm{D}_{\mathrm{f}}$, is 13 times better than what the DOE order calls for (366/27.8), and 58 times better when the upper $\mathrm{D}_{\mathrm{f}}$ value estimate is used for the comparison.

The calculated total amount of adsorbed cesium in the CoHex cartridges is $17,528 \mu \mathrm{Ci}(55,526.5 \mathrm{gallons} \mathrm{x}$ 3.785 liters/gallon $\times 1000 \mathrm{~mL} /$ liter $\times 8.34 \mathrm{E}-05 \mu \mathrm{Ci} / \mathrm{mL}$ ), which is approximately $2,921 \mu \mathrm{Ci}$ per cartridge. At the end of the demonstration, the external radiation dose rate on the stainless steel housing holding the CoHex cartridges was $70 \mathrm{mR} /$ hour at $30 \mathrm{~cm}$ (gamma).

Since treated basin water was released back into the disassembly basin only about 30 meters away from the 
PADU intake line, one would expect a dilution effect, that is, lower cesium concentration at intake line with time. The data collected shows that this is not the case (Table 3). There are, in fact, no significant or measurable changes in cesium concentration from the basin water acquired at the beginning and at the end of the demonstration. The average cesium concentrations for the first 20 hours of PADU operation and the last 20 hours are, respectively, $8.41 \pm 0.43 \mathrm{E}-05 \mu \mathrm{Ci} / \mathrm{mL}$ and $8.31 \pm 0.37 \mathrm{E}-05 \mu \mathrm{Ci} / \mathrm{mL}$. The above result was expected because of the large volume of water in the R-Building disassembly basin $(5,000,000$ gallons $)$ and the possibility for the leaching of equilibrium cesium in the basin sludge back into the liquid phase.

Data used in the plots in Figures 2-5 are from the first 74 hours of continuous operation of the PADU, that is, before the change out of the coarse pre-filters. Pressure reading on the coarse pre-filters housing showed a significant change every 24 hours. The increase in pressure per 24 hours time period averaged about 10.4 psi, Figure 2. The fine pre-filter pressure changes were significantly lower at about 1.0 psi per 24 hours, Figure 3 . These changes in pressure due to the clogging of the pre-filters can be attributed to the presence of particulate matter in the R-disassembly basin. However, recent discussions and a better understanding of the basin water chemistry have shown that the basin water is super saturated with calcium ions (Table 2b). The super saturated calcium ion media, when disturbed such as when the water comes into contact with the prefilter membranes, may precipitate as carbonates and thus may be the main pre-filter clogging culprit. A plot of the PADU continuous operation time (hours) versus pressure difference across the coarse and fine prefilter cartridges, Figure 4, shows that the pressure changes across the pre-filter units was 9.34 psi per 24 hours.

After 74 hours of continuous processing of R-disassembly basin water through the PADU, the coarse prefilter pressure reading went up to $61 \mathrm{psi}$ and since that was on a weekend, the PADU was shut down. The six coarse pre-filters cartridges were changed after that weekend and the unit brought back into service. At 10.4 psi per 24 hours pressure increase the PADU would have automatically shut itself down by the end of that weekend, as it was designed to operate if the pressure of the system went above 100 psi.

The R-Disassembly Basin water flow rate across the PADU, based on the totalizing flow meter, averaged 22.14 liters (5.85 gallons) per minute. The flow rate determined from a plot of total volume of water processed with time, Figure 5, showed that the actual flow rate was 22.71 liters per minute (slope of the linear plot).

The calculated CoHex cartridge intake surface area is $0.019 \mathrm{~m}^{2}$ (all six cartridges in parallel), and based on a linear flow rate of 22.71 liters per minute, the flow rate per unit area was $1,195.80$ liters $/ \mathrm{minute}^{2} \mathrm{~m}^{2}(29.35$ gallons/minute/ $\mathrm{ft}^{2}$ ). This number will seem to suggest a very short contact time between the CoHex and the basin water, probably in seconds. This flow rate per unit area meets industrial requirements. Most ion exchange based polishing applications in the industry are operated at flow rates 611.13 to 2,037.1 liters $/ \mathrm{minute} / \mathrm{m}^{2}\left(15-50 \mathrm{gal} / \mathrm{min} / \mathrm{ft}^{2}\right)(4)$.

The decontamination plan for the R-disassembly basin would eventually involve simultaneous removal of cesium-137 and strontium-90. However, due to the high concentration of calcium ions (up to12 ppm in the supernate, Table 2b), which is an effective competing agent in Sr-90 removal using ion exchange approach, calcium would have to be removed before any effective Sr-90 decontamination can be achieved. Among some of the proposed approaches to limiting the effect of calcium is the adjustment of the basin water $\mathrm{pH}$ to about a $\mathrm{pH}$ of 10 with either sodium hydroxide or preferably sodium carbonate. This would result in the precipitation of the calcium as the carbonate followed by the application of centrifuge/filter techniques to remove the resulting calcium carbonate precipitates. The Cs-137 and Sr-90 bearing effluent would then be passed over cesium and strontium removing ion exchange columns or cartridges in series. The concentration of magnesium in the basin water, at $1.19 \mathrm{mg} / \mathrm{L}$ in the supernate, is also quite large in comparison to the concentration of strontium-90. Its effect as a competing ion in Sr-90 removal using ion exchange techniques 
may need further investigation.

\section{Conclusions}

- The linear flow rate, approximately 22.71 liters of R-Disassembly Basin water per minute, is sufficiently low enough to ensure that there is sufficient contact time for ion exchange reactions in the spiral membrane /CoHex arrangement.

- This flow rate translates to approximately $1,195.8$ liters $/$ minute/m² 29.35 gallons per minute per square feet), which would meet most end-user flow rate requirements for polishing applications to remove cesium from aqueous stream (4).

- Cesium concentration in the Vertical tube storage area of the R-disassembly basin, where this demonstration was carried out, is $8.34 \pm 0.245 \mathrm{E}-05 \mu \mathrm{Ci} / \mathrm{mL}$. This value is in agreement with the documented average R-disassembly basin cesium- 137 concentration of $8.25 \mathrm{E}-05 \mu \mathrm{Ci} / \mathrm{mL}$.

- The estimated minimum cesium-137 decontamination factor $\left(\mathrm{D}_{\mathrm{f}}\right.$ obtained with this CoHex in a cartridge treatment, based a minimum cesium detection limit of $2.277 \mu \mathrm{Ci} / \mathrm{mL}$, is 366 . This $\mathrm{D}_{\mathrm{f}}$ value, at the R-Disassembly basin cesium-137 concentration of $8.34 \mathrm{E}-05 \mu \mathrm{Ci} / \mathrm{mL}$, is at least 13 times higher than the DOE requirement for the R-Disassembly basin. At lower cesium-137 detection limit extrapolation $(6.523 \mathrm{E}-08 \mu \mathrm{Ci} / \mathrm{mL})$ it can be shown that the actual $\mathrm{D}_{\mathrm{f}}$ is greater than 1600 .

- After processing over 210,000 liters (>55,000 gallons) of the R-disassembly basin water there was no cesium-137 breakthrough.

- The calculated total amount of cesium-137 adsorbed on the CoHex in a cartridge unit is $17,528 \mu \mathrm{Ci}$, which is approximately $2,921 \mu \mathrm{Ci} /$ cartridge.

- The pressure reading change across the PADU coarse and fine pre-filter units was 9.4 psi per 24 hours time period. The pressure reading changes were highest on the coarse pre-filter at 10.4 psi per 24 hours. The pressure reading changes on the fine pre-filter was approximately 1.0 psi every 24 hours.

- At this filter clogging rates in the R-Disassembly Basin, the coarse pre-filter will need to be changed approximately every 6.7 days and the fine pre-filter every 70 days for continuous operation of the PADU. Note that the PADU auto shut-off mechanism comes into play, when the pressure across the pre-filters or any part of the system is greater than 100 psi.

- At the end of the approximately 7 days demonstration the external gamma radiation dose rate on the 11-gauge stainless steel housing (CoHex cartridge housing) was $70 \mathrm{mR} / \mathrm{hr}$ at $30 \mathrm{~cm}$.

- It would be of scientific interest to operate the PADU continuously until the CoHex is saturated with chemisorbed cesium-137 (breakthrough point). Such breakthrough information is useful in determining and comparing the theoretical and the actual volume of cesium bearing waste water that can be processed, as well as the validity of the batch distribution coefficient $\left(\mathrm{K}_{\mathrm{d}}\right)$ for the ion exchange material (potassium cobalt hexacynoferrate). However, such lengthy PADU operations will lead to radiation safety issues for the operators. Each CoHex cartridge will be overloaded with chemisorbed cesium up to the point where it becomes too "hot" to work with safely during dislodging/CoHex change and transport operations. In other words, a high radiation environment $(>100 \mathrm{mR} / \mathrm{hr})$ would be created. Therefore, only a maximum of seven days of continuous PADU operation before change of CoHex cartridges is recommended. These CoHex cartridge change operations (opening of the 11gauge stainless steel housing) must be carried out under water (inside the disassembly basin) using appropriate tools. The cesium-137 bearing cartridges must be shielded during transportation above the disassembly basin.

- An appropriate strontium-90 ion exchange absorber, preferably an inorganic material such as sodium titanate, would also be incorporated in series with the CoHex to evaluate the efficiency of Sr-90 removal in the presence of ppm levels of competing calcium ions in the R-Building Disassembly Basin. 
- Future plans call for the designing of another PADU, which will be capable of processing the RDisassembly Basin water at 190 liters (50 gallons) per minute.

\section{Acknowledgements}

The authors wish to thank the following people who contributed to this work: Lynda Wingard, Cecil Woodard, John Hage, Janice Breedlove, Horace Fowler and Henry Bolten. This work was performed under the auspices of the U.S. Department of Energy by the Savannah River Technology Center. Funding was provided by Department of Energy Efficient Separations and Processing (ESP) Crosscutting program.

\section{References}

1. J. B. Pickett, Analytical Results of the 1997 R-Disassembly Basin Sampling Program (U), FDDEng.-98-0029, Westinghouse Savannah River Company, Savannah River Site, Aiken, SC.

2. "Demonstration of Radionuclides Removal at the 105-N Basin using the 3M System", Report BHI00759, Rev. 0, Bechtel Hanford, Inc. Rich, Washington.

3. Herbst, R. S., K. N. Brewer, T. A. Todd (Lockheed Idaho Technologies Company), L. A. Bray (PNNL), T. Kafka, R. L. White (3M). " Decontamination of TAN Injection Well Water using 3m Web technology'. Report, November 1995, INEL-95\0589, Lockheed Idaho Technologies Company, Idaho, Falls, ID.

4. George P. Simon, " Ion exchange training manual", Van Nostrand Reinhold, New York, 1991.

\section{Click here for Picture}

Figure 1a. R-Disassembly Basin PADU test equipment schematic

\section{Click here for Picture}

Figure 1b. R-Disassembly Basin PADU Engineering Design Schematic

\section{Click here for Picture}

Figure 1c. R-Disassembly Basin PADU Photo

\section{$\underline{\text { Click here for Picture }}$}

Figure 2. Pressure changes as a function of time for the 0.45 micron (coarse) filter. Pressure changes per 24 hours on the coarse filter was 10.4 psi (see slope).

\section{Click here for Picture}

Figure 3. Pressure changes as a function of time for the 0.1-micron (fine) filter. From the slope data, pressure changes on the fine filter was 1.0 psi per 24 hours.

\section{$\underline{\text { Click here for Picture }}$}

Figure 4. Pressure difference across the coarse and fine pre-filters as a function of time. The slope of the plot 
gives a value of 9.34 psi per 24 hours. Hence, filters had to be changed approximately every 7 days during continuous operation [initial system pressure $\sim 30 \mathrm{psi}$ and auto upper level shut-off pressure of $100 \mathrm{psi}$ ].

\section{$\underline{\text { Click here for Picture }}$}

Figure 5. Volume of R-Disassembly Basin water processed before change of coarse filter. R-Basin water flow rate through the COHEX cartridges, based on slope of the plot, was 6.0 gallons per minute. The calculated flow rate was 5.85 gallons per minute.

[**] Process time in hours is interval between sampling periods.

[+] Weight mean activity; ADS \#s 3-104464 to 3104468 and 3107658 to 3107706.

[+] Weight mean activity; ADS \#s 3-104464 to 3104468 and 3107658 to 3107706.

[*] Less than minimum detection limit; averaged 2.277E-07 and 6.523E-08 Ci/mL for 1000 seconds and 10,000 seconds real time counting, respectively.

$[++]$ Feed was not analyzed. 